\title{
The Relation of Human Being and Environment in the Cultural Event of Laesan Performance
}

\author{
Siti Nur Hasisah ${ }^{* 1}$, Oktiva Herry Chandra ${ }^{1}$ \\ ${ }^{1}$ Department of Linguistics, Faculty of Humanities, Diponegoro University, Semarang - Indonesia
}

\begin{abstract}
Laesan is a traditional art that comes from the word "laesun" which means "suwung" or empty. In the show, it tells the story of a human being from the womb to return to the grave which is told through a dance accompanied by songs according to the session. This study aims to describe the relationship between humans and elements of communication and communicative actions in the cultural event of laesan performance. This research applied a qualitative descriptive approach with ethnographic studies of communication. The research data were in the form of fragments of speech and actions involved in laesan performing arts. The research method was ethnographic and participatory. The results show that laesan art communication has a communication system related to the sequence of GASKENPI components. The forms of messages in laesan art are mantras and song lyrics. The act of communication in laesan art is divided into two: (1) the act of communication between laesan players and the empty atmosphere of the universe, (2) the act of communication between laesan players and the audience. These two forms of communication have functions related to environmental preservation which include the songs entitled Ella Ello, Bandhan, Luruo Sintren, and Santrine Dodol Gambir.
\end{abstract}

\section{Introduction}

Laesan art is a Lasem folk art in a dance accompanied by typical songs (tetembangan) and music (tetabuhan). Besides combining vocal and instrumental arts, Laesan also uses literary art in the form of prose so that it blends beautifully. "Laesan" comes from the word "laesun" which means "suwung" or empty. Meanwhile, according to another version, "laesan" comes from the word "laes" or people who become laesan; laes resembles death or is often said to be between dead and not or empty. Laesan is the traditional art of the Lasem community, which has been carried out since ancient times until now. Laesan in Lasem is not an art that functions as a ritual of worship or to bring in spirits but is purely just entertainment in which there is an element of trance.

The Laesan stage is carried out starting from the arrival of a person who would become laesan into the middle of the field, which a circle of spectators has surrounded. Then the incense smoke is ignited and covered with a chicken cage covered with a white cloth. After that, the person who becomes laesan is tied up by the handler and locked up. That is when the opening song entitled Ella Ello begins with the lyrics, namely

* Corresponding author: $\underline{\text { author@email.org }}$ 
[Lailahaillallah muhammadurrasulullah]

'There is no god but Allah, Prophet Muhammad the messenger of Allah'

[Pengerane nggawe laes]

'Pengeran make laes'

This lyric is accompanied by the music produced with three bamboos and two junks '(water vessels made of clay), consisting of a large and a small junk. This is done by two panembang (singers). Ella Ello is then continued to be sung until the lais came out of the cage. It is continued with the second, third, and so on until the last session. The closing is done by singing Loro Tangis Kelayung-layung. Then the laes realize, fall, and cry; the laesan performance is over.

These stages or sessions must not be reversed; they must be in sequence from beginning to end. This implies a picture of human life or living things from nothing to being and back to non-existent. As long as the show has started, the songs sung must be standardized and not changed. Unless the singer must comply during the dolanan session, the laes asks for specific songs to be sung. All laesan players are men. In Islamic culture, women must be guarded, both genitals, voices, and all members of their bodies. Therefore, in Javanese culture in Lasem-whose majority is Muslim, it is considered taboo for women to act.

Furthermore, what distinguishes laesan and sintren is the player. Laesan is played by men, while women play Sintren. In addition, there are variations in the performances of using glasses and the touch of a modern musical instrument. In Lasem, everything about laesan is still purely traditional, including the attributes, the musical instruments, which are still percussion, and the songs. It still maintains naturalness and plainness.

The local community understands Laesan in the Lasem area as having absolutely nothing to do with spirits as dancing in laesan performance is not held in a trance. The trance is stiff, while laesan is bland. The exciting or unique thing is that the laes is male, but he possesses a female spirit.

Currently, laesan is only displayed when big holidays arrive or when there are cultural events. This is different from the past when the Lasem community often called the players to perform when they had a party at their houses. This condition puts the laesan group in Lasem has decrease in number. It can even be said to be rare or almost extinct. This happens because it is rare for young people to be interested in pursuing or studying this art. The only laesan group that exists nowadays is the one led by Yon Suprayoga. This laesan group has still maintained the standard of laesan system since ancient times. The simplicity and simplicity of laesan are traditional art forms considered essential to be preserved by the younger generation, especially the Lasem youth.

The communication events and functions and the components of the laesan show sequence can be revealed through the ethnographic study of communication in this research. The existing roles of the players involved can predict a unique communication phenomenon. This study was conducted to find out the form of communication in the cultural practices of the Javanese Islamic community through laesan art.

\section{Literature Review}

This This literature review section consists of two things, namely previous research and the theoretical basis used to analyze the data. Some of the previous studies discussed and described laesan and language research with the ethnographic theory of communication.

Research on laesan and ethnography of communication was conducted by Budilestari [1] to discuss the existence of Laesan Rukun Sentosa group in the tradition called ruwatan in the rapid flow of globalization. The results show that the existence of 
Laesan Rukun Santosa can be seen through the tight schedule of performances that are carried out. The supporting factors for the existence of Laesan Rukun Santosa are divided into two, namely internal factors and external factors. Internal factors are (1) finance, (2) players, and (3) performance format. External factors are (1) appreciator/audience and (2) Government Tourism Office of Pati Regency. The inhibiting factors for the existence of Laesan Rukun Santosa are (1) management and (2) competition with modern performances.

Furthermore, Anggrahita and Sunarto [2] found out that laesan is a means of entertainment for the Lasem community. Besides functioning in ceremonial activities, laesan is also often displayed just for the familiar spectacle to evoke a sense of aesthetics in the community. Laesan is seen as a ritual that does not follow religious norms because it contains mystical elements and is also heretical. It uses offerings to invite the spirits of the ancestors, namely the nymphs. This has resulted in rejection from some of the Lasem community, especially the santri. The existence of a mixture of Islam and Javanese culture (Kejawen) should strengthen the community to revive laesan as the original art of Rembang as a mere form of entertainment.

Kusumastuti's [3] research on laesan as a coastal art phenomenon exemplifies that laesan is presented with various elements, namely (a) three parts of the presentation, namely the beginning of the show, the essence of the show, and the end of the show, (b) stage equipment; (c) accompaniment; (d) make-up and clothing; (e) representational and non-representational dance movements. The symbolic interaction process occurs in every part of the show. The symbols that make up the symbolic interaction process include incense, offerings, accompanying songs, the meaning of trance in laesan.

The fourth research explains that laesan is a ritual art that is related to the mystical and magical. In addition, no research examines laesan in Lasem through ethnographic studies of communication. This research will complement the laesan study to (1) describe laesan art from the communication patterns that take place, (2) explain the roles involved in communication events when it is performed, (3) find communication patterns formed by roles in laesan, and (4) find the meaning of laesan art seen from the communication elements that shape communication events in laesan art.

Another research was conducted by Arifiani [4]. The findings show that laesan art has a local communication system that is interwoven in communication components with the acronym GEPNIKAS, namely Genres, Ends, Participants, Norms, Instrumentalities, Keys, Act sequences, and Settings. The message form in laesan art is divided into three types: mantras, parikan, and song lyrics. The act of communication in laesan art is divided into two. First is the act of communication between laesan players and the spirit of an angel or a creature that can bring out supernatural powers. These communicative actions are manifested in supplications, wishes, and prayers. The second is the act of communication between laesan players and the audience. This communicative action is manifested in requests, statements, invitations, and notifications.

The previous research was conducted by Shanks [5] entitled "Magic Incantation Bowls," discussing the historical meaning of ancient Jewish magic spells. The bowl contains inscriptions in Hebrew Aramaic. The public uses this inscription for protection against evil spirits. Diseases that belong to Satan can be cured by using the bowl as a medical or magical treatment. The bowl is made for a specific purpose and offers many details about life in Babylonia between the 3rd and 7th centuries of the Common Era.

The difference between these two studies and mine is that they examine mantras as an element of communication components in laesan art performances. Meanwhile, my research discusses communication events in laesan arts.

Laesan art illustrates the existence of communication interactions between players who take part in this art. Communication between players in laesan is not the same as in everyday communication; its language use differs from the general. The uniqueness of the 
interaction patterns of laesan players must be carried out and researched to reveal language, communication, and culture in laesan art performances that demonstrate the use of ritual language. Purwoko [6], Moleong [7], and Spradley [8] states that ethnographic research has been carried out in various cultures to find similarities and differences in the way people speak to each language user. Researchers used an ethnographic communication approach to reveal the phenomenon of language use in laesan art.

\section{Research Method}

The data collection stage used observation, in-depth interviews, and focus group discussion methods in this study. Furthermore, the researchers utilized the referential equivalent analysis method with the data analysis technique proposed by Kuswarno [9]. According to Sudaryanto [10], the equivalent method is a research method in which the determining tool is independent or not part of the related language. The data in this study were in the form of all the utterances involved in laesan art performance in Soditan Village, Lasem Sub-district, Rembang Regency. Meanwhile, the data sources were all the players involved in the show, consisting of laes, laesan guards, pawing (handler), panembang (singers), junk drummer, and bamboo musician, as well as a leader of Laesan group - who was the only interviewee in this research. This qualitative descriptive study used an ethnographic communication approach to describe the communication behavior that exists in this laesan art performance. The final stage of data analysis in ethnographic research is interpretation. Taking conclusions by researchers would be carried out at this stage.

\section{Results and Discussion}

In this section, the researchers would present the results and discussion under the formulation of the problem and the research objectives consisting of several things, namely (1) communicative behavior and message form during communication events in laesan art performance; (2) the relation of a series of communication elements to the communication event in a laesan art performance.

\subsection{Communicative Behavior and Message Form in Communication Event in Laesan Performance}

Communication behavior in laesan is interwoven in five sessions, showing different sequences of communicative behavior patterns. Behavior communicative communication of a message, containing the form, content, and functionality through the Javanese songs, is expressed by panembang (singers). These Javanese songs are divided into two forms, namely mantras or spells and song lyrics. In particular, the two forms of communication messages are used in communicative behavior at each session in laesan. The following is the communicative behavior in each session: opening, taking-off-bandan, game, treatment, and closing sessions.

\subsubsection{Opening Session}

In this In this session, the panembang (singers) sing Ella Ello. This song is a lyric containing a prayer request to God of the universe so that the laesan show will run smoothly. Previously, the lyric of this song was ella laillollah ello. Around the 90s, the lyrics became lailahaillallah. This is influenced by the tongues of ancient people that were different from the tongues of people nowadays. Besides, the knowledge of the ancients 
about Islam was not as proficient as Muslims today, who are very fluent in pronouncing lailahaillallah muhammadurrasulullah. Even though the song lyrics have developed, it does not change the essence or content of this song. Instead, it displays the lyrics that the previous person meant.

The communication between the laesan player and the Lord of the Universe is in the form of an act of request, which is manifested by repeatedly singing the song Ella Ello. Then, the laesan player shows their symbolic hope of God to bring trance power to laes. Communication during this session is established with repeated requests and wishes. In this session, laes dances with typical dress and enters the cage provided. This stage is carried out starting from the arrival of a person who would become laes into the middle of the field, which a circle of spectators had surrounded. Then the smoke of incense is ignited and covered with a chicken cage that has been covered with a white cloth. The laes are then tied by the handler and locked up. That is when the opening song entitled Ella Ello begins with the lyrics, namely.

[Lailahaillallah Muhammadurrasulullah]

'There is no god but Allah, Prophet Muhammad the messenger of Allah' (15a)

7

8

[Pengerane nggawe laes] 'pengeran make laes'(8e)

$4 \quad 2 \quad 2$

[Laes] 'laes' (2e)

2

It is grown and then sprinkled with three bamboos and two 'bass-like' junks consisting of large junks and small junks. This is done by two persons in charge.

\subsubsection{Taking Off Bandan Session}

In this session, the singers sing Uculana Bandan. This song is a mantra that gives a wish addressed to laes so that it is susceptible and has the magical power to untie the rope that binds laes' hands. Communication, in this session, is an effort to unify and gain power. The power of suggestion and request is strengthened. Here are the lyrics of the second song.

[Uculna Bandanira]

a1 b1

[Iki sari laes dunung ala dununge]

a2 b2 c2

[sing nguculi bahu kiwa]

a3 b2

[kejaba pengeran ira]

a4 b4 'untie the rope'

'this is the origin of laes from the origin'

'that releases the left hand'

'except our pengeran'

The song is repeated over and over. When it is sung, the laes has changed his clothes from his usual clothes to all black, and the ties on his hands are also taken off. He starts in a state between conscious and not or experiencing a trance emptiness. He starts dancing in the middle of the field, accompanied by the handler. Over time, the laes will fall and then be put in the cage again. 


\subsubsection{Playing Session}

In this session, the panembang sings the dolanan (playing) song. They are in the form of mantras and lyrics. In this session, the panembang sings the playing song in the form of mantras and song lyrics. At this moment, laes, who is previously in the cage, is opened. This implies that a human goes through the process of being conceived, then born, and when he is born, he passes through childhood which possesses a period of playing. When the laes is set free, he then comes out and plays around dancing. This part implies that life in this world is only playing - just playing the role of the Creator. This life is not forever; it will come to an end. Several songs are played, for instance, the song entitled Santri. The lyrics are as follows.

(1) [Santrine ajar pencak] 'the students learn pencak silat (martial arts)'

a1 b1

[Santrine dodol gambir] 'the students sell gambier'

a2 b2

Then, there is the game with the song Jaran Dawuk. This game is usually played by children-although adults can also play. The process is that the little child has his ears blown by the laes who is assisted by the handler. Then this little boy dances with a broom which was considered as a horse. The lyrics are as follows.

(2) [jarane jaran dhawuk] 'The horse is a dhawuk horse'

a1 b1

[jarane mbok sinawuk] 'horse on a rope'

a2 b2

In addition, there are several other playing songs such as Enca Enci, Kembang Gedhang, and Kembang Turi. The lyrics are as follows.

(3) [Enca-enci kecambah kacang kuwaci] 'enca enci sprouts of kuwaci beans'(12i)

$\begin{array}{llll}4 & 3 & 2 & 3\end{array}$

[kecambahe kacang kuno] 'old bean sprouts'(8o)

$4 \quad 2 \quad 2$

[manuk anguk-anguk ning jendhelo] 'bird peers at the window'(10o)

$24 \quad 4 \quad 1 \quad 3$

[jendhelone gawean londho] 'the window is made in dutch' (9o)

$4 \quad 3 \quad 2$

[sing ngunjungi awak iro] 'coming to us' (80)

$\begin{array}{llll}1 & 3 & 2 & 2\end{array}$

(4) [Kembang-kembang turi] 'flowers of turi'(6i)

4

[mbedhodhok wulan ndadari] 'suddenly the moon is full' (8i)

$3 \quad 2 \quad 3$

(5) [Mbang-kembang gedhang] 'banana flower' (5a)

32

[sing diglandhang dadi laesan] 'being pulled so laesan' (9a)

$\begin{array}{llll}1 & 3 & 2 & 3\end{array}$ 
In this session, there is an interaction between laes and the audience. For example, when one of the songs above is sung, one of the spectators who is selected and touched by laesan will trance and dance with playing pencak silat (martial art).

The songs above reveal that living in this world is just like playing, not forever so that it is expected to do good things to the environment and others, not to damage and not to be evil.

\subsubsection{Treatment Session}

In this session, the panembang sing song Luruo Laesan. This song is a mantra. At this moment, there is also an interaction between the laes and the audience. If anyone wants to join the laesan dance, there will be a transfer process from the laes to the audience, using the audience's ears being blown by the handler, and then one of the selected spectators will be in a trance. The communicative action, which contains the command and statement power of this song, can attract the attention and focus of the audience to the magic of laes who is transferring energy to the audience or substitute laesan players.

Before the game is started in the initial session, offerings containing flowers, golden bananas, and cigarettes are provided and placed on the tray. This process is accompanied by the song Luruo Laesan.

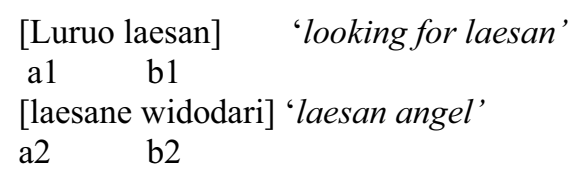

Then the Laes danced with the tray with offerings on it; then he would give the contents of the offerings to the person he likes. If the audience is given flowers, usually the flowers are taken home and given water in a glass until overnight. In the morning, the water from the soaking is given to the sick family members if there is any. This reveals that in the realm of life, humans must experience illness in which humans must be patient and sincere but also try to heal or make efforts even though they will eventually die too.

\subsubsection{Closing Session}

The last session is the closing which is marked by singing the song entitled Loro Tangis Kelayung-layung. This song is a song lyric. This session expresses some communicative behavior to the audience through the messages conveyed. Communicative action advises humans that all of us will eventually die and leave everything in the world behind. When facing death, it is illustrated how difficult it is for humans to go through this critical period, which is very torturous, painful, and arduous. Furthermore, nothing can help us except God the Almighty by considering our deeds while in the world.

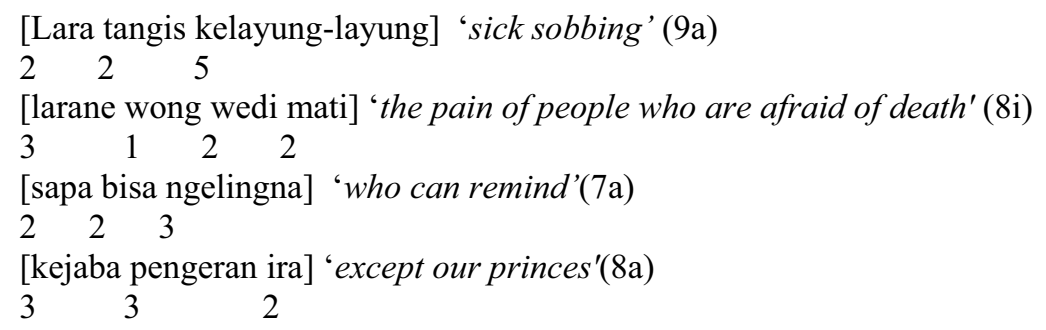


After some time, the audiences wait for the laesan to dance in trance. When the songs and music are played in false and the rhythm is spoofed, the Laes will soon come to his sense, then fall and cry. Other than the handler, the laesan control device is the panembang (singers) and the penabuh (musician).

\subsection{Relationship of a Series of Communication Elements in Communication Events in the Laesan Performance}

Laesan performance has a peculiarity of speech elements that do not refer to the order of the speech components compiled by Hymes, namely SPEAKING. The shift in the order of communication components in laesan arts shows a local communication system typical of everyday communication or other types of communication. The relationship of a series of communication elements is based on the paramount importance of standard rules in an element of communication. Ordering the elements of this communication will facilitate and understand the communication organization system in laesan. The order in laesan is GASKENPI. This acronym is for Genre, Act sequences, Settings, Key, Ends, Norms, Participants, and Instrumentalities.

Genre is the first set of communication elements that exemplify the uniqueness of the rules of the communication system in laesan. This first component must be considered to describe the local communication system in art, especially in laesan.

Genre contains rules for implementing a traditional art that is ritual in nature. This provides concepts and knowledge, especially for researchers and generally for laesan art connoisseurs of spirituality. The ritual process is usually carried out in a unique and vital activity. In this connection, genre becomes an abstraction of art patterns pointing out trance.

Act sequences are a series of communication events that must occur. In this laesan show, five sessions take place. At each session, participants give specific roles. Each participant's role with one another is irreplaceable. The participants, one laesan handler, one laesan dancer, two singers, three junk and bamboo drummers, and three handler helpers, are in one laesan art venue. The participants put themselves by the rules or procedures for performing laesan.

Setting raises standard rules. This rule supports the smoothness and virtue of achieving the primary goal of achieving the trance effect perfectly. Laesan is held during the day or at night. The implementation of laesan during the daytime causes delays in the process of achieving magical effects. This makes the time needed for laesan to enter the trance process longer. It is best to carry out the laesan at night. It is easier to create a solemn atmosphere, making it easier for the handler to control the laes.

Key to the implementation of the laesan art is the handler and laesan. The main objective of performing laesan arts is to show the power of trance. The rules in the previous component lead to the domination of the role of the critical players in the implementation of communication events in laesan. Each communication component is composed of primary and secondary or primary and complementary elements.

The end or goal of laesan art is influenced by the conception of trance in laesan art. This relates to the background and goals to be achieved in its procession. This objective is still abstract, so that it will be manifested in other components of communication.

Norms or rules of laesan art govern during the interaction process between laesan players. The relationship between the players raises special rules and binds all the players involved in laesan. Laesan players must obey the rules to achieve the goals as laesan is magical and mystical. This implies the emergence of rules and implementation rules that must be obeyed in its implementation. Compliance with norms can support the achievement 
of the goal of implementing the laesan perfectly. The perfection of the objective is realized when the trance changes in laesan dancers take place quickly.

Participants or players of laesan arts have different roles in realizing the abstraction of art rules that represent ritual processions. The handler of laesan appears as the paramount and supreme player. The existence of the handler in laesan art has highlighted the magical characteristics of art. A handler is a person who has the ability and knowledge in laesan control. The presence of a laesan dancer presents his specialty. Then, laesan art is complemented by the action of a dancer in the presence of songs and music played.

Instruments or tools are to distribute and support the components of the previous communication. The rules between the players give rise to the need for style. Instruments in the art of laesan are tools that must be fulfilled. This is related to realizing the goal of achieving magic in laesan. The instrument appears with the boundaries of interaction between players and spectators.

\section{Conclusion}

There are several conclusions about laesan performance. The communication components that play a role in laesan are interwoven in the order of the communication components from the most dominant with the acronym GASKENPI. These rules indicate local communication patterns in laesan. This local communication pattern shows the characteristics of laesan art in detail.

Based on each song's form, content, and function, the songs in the laesan show are classified into two types, namely mantra and song lyrics. Two singers sing Javanese songs in five sessions during the laesan art scene. Each session contains a communication act conveyed through Javanese songs with a typical laesan port. These songs become messages..

\section{References}

1. U. Budilestari, Eksistensi Kesenian Laesan Rukun Sentosapada Tradisi Ruwatan Dalam Pesatnya Arus Globalisasi (2017)

2. N. H. Anggrahita, Sunarto. Kesenian Laesan Di Kabupaten Rembang: Kajian Fungsi Dan Konflik, Catharsis Journal of Arts Education 5 (1) (2016)

3. E. Kusumastuti, Laesan Sebuah Fenomena Kesenian Pesisir: Kajian Interaksi Simbolik Antara Pemain dan Penonton, Harmonia Jurnal Pengetahuan dan Pemikiran Seni 7 (3) (2006)

4. E. Arifiani, Peristiwa Komunikasi dalam Kesenian Laesan di Kabupaten Pekalongan (Kajian Etnografi Komunikasi), Tesis Undip Semarang (2020)

5. Shanks, Magic Incantation Bowls (2007)

6. J. H. Purwoko, Working Papers (2015)

7. J. Lexy. Moleong, Metode Penelitian Kualitatif, Bandung, Remaja Rosdakarya (2002)

8. James P. Spradley, Metode Etnografi, Yogyakarta, Tiara Wacana (1997)

9. E. Kuswarno, Metode Penelitian Etnografi Komunikasi, Bandung, Widya Padjajaran (2011)

10. Sudaryanto, Metode dan Aneka Teknik Analisis Bahasa, Yogyakarta, Sanata Dharma University Press (2015) 